\title{
KEPUTUSAN MAHASISWA PENGUNJUNG PERPUSTAKAAN MENJADI ANGGOTA UPU PERPUSTAKAAN UNIVERSITAS GADJAH MADA
}

\author{
Decision of Students Visiting Gadjah Mada University Library \\ to be Library Members \\ Lilik Kurniawati Uswah ${ }^{*}$ Partini $^{* *}$ dan Ida Fajar Priyanto ${ }^{* * *}$
}

\begin{abstract}
The student's decision to be the member of a library is an expression of their need od information. This decision is influenced by intern al and external factors, such as social, milieu and motivation.

There are so many kinds of library in UGM: faculty, research center, diploma program, etc. That makes not all UGM students want to become the members of universitylibrary. The success of a library can be measured by the quantity and quality of its members, such as increasing of active users of potential users.

The problems are: why do UGM students choose or do not choose to become the member of UPU library? What are the factors influenced this choice? Is there any significant difference between the sex, education, or development that they take?

The method that is used is eclective qualitative and explanatory research, it explains causal relation between the variable through examining the explanation. The population are the visitors of UGM library, such as UGM students (D3, S1, Pascasarjana) and also from outside of UGM. The datas are taken by quisioner, interview, and also examining some documents and similar research. Sample method is used to take 105 responds of library unit I in Bulaksumur and Unit 2 in Sekip.

Majority of students have middle decision to become the member of the library. It means that according to them, a library is important for the, but it does not mean that this makes them to become the member of it although they feel that they can get some information from the book available.

The research indicates that social factor, milieu and motivation together influenced the students' decision to become the member of UPU UGM library. The milieu indicates by the support of every family to enforce the members of it to read more and more. And also the lecturers motivated the students to read more and more and to become the member of UPU UGM library. But the most variable that influenced the students to become the member of UPU UGM library is their motivation to aquire their need of information and prestation.
\end{abstract}

Keywords: Decision, Library, Motivation

\footnotetext{
* Perpustakaan Universitas Gadjah Mada, Yogyakarta

** Fakultas Ilmu Sosial dan Ilmu Politik Universitas Gadjah Mada, Yogyakarta

*** Perpustakaan Universitas Gadjah Mada, Yogyakarta
} 


\section{Pendahuluan}

Sebagai pusat informasi, perpustakaan di perguruan tinggi mempunyai posisi penting bagi keberhasilan studi mahasiswa. Pengguna perpustakaan merupakan barometer keberhasilan suatu perpustakaan. Keberhasilan perpustakaan terutama diukur dari kuantitas dan kualitas pengguna jasa perpustakaan, diantaranya peningkatan active user yang merupakan pengguna aktif dari potensial user.

Jika dimanfaatkan secara maksimal, perpustakaan akan mempunyai nilai tambah bagi penggunanya. Wells [1995] cit. Achmad [1999] berpendapat bahwa bermacam-macam sumber daya dan jasa perpustakaan yang dimanfaatkan oleh mahasiswa dapat berpengaruh pada keberhasilan akademiknya. Ada korelasi positif antara prestasi akademik [indeks prestasi] dengan peminjaman buku di perpustakaan. Achmad, dalam penelitiannya di tahun 1997 tentang pengaruh penggunaan perpustakaan terhadap keberhasilan akademik mahasiswa ITS membuktikan bahwa mahasiswa yang sangat sering meminjam buku, nilai IPKnya $13,86 \%$ di atas rata-rata fakultas. Sementara mahasiswa yang sering meminjam buku, nilai IPKnya 4,8\% di atas rata-rata. Mereka yang jarang dan sangat jarang meminjam buku nilai IPKnya masingmasing $2,62 \%$ dan $10,47 \%$ di bawah rata-rata.

Pengguna perpustakaan merupakan barometer keberhasilan suatu perpustakaan. Pengguna merupakan bagian yang tak terpisahkan dari suatu sistem perpustakaan. Pengguna secara tidak langsung merupakan target dari suatu sistem perpustakaan. Fleming [1990] secara tegas mengatakan bahwa pengguna adalah mereka yang menerima manfaat utama dari suatu sistem informasi yang diciptakan. Perpustakaan didirikan dengan tujuan utama untuk memberikan layanan atas kebutuhan informasi penggunanya. Oleh karena itulah pemahaman mengenai pengguna sangat diperlukan dalam kaitannya dengan proses interaksi yang terjadi di perpustakaan.

Perpustakaan perlu mengetahui beberapa karakteristik pengguna terutama dalam menunjang aktivitasnya. Penna [1998] cit Retno
[2002] mengungkapkan karakteristik tersebut adalah:

1. Individual or group yaitu apakah si pengguna datang ke perpustakaan sebagai individu atau sebagai suatu kelompok.

2. Social situation, yaitu aspek sosial dari pengguna perpustakaan.

3. Leisure or necessary factor, yaitu apakah pengguna berkunjung ke perpustakaan untuk sekedar mengisi waktu luang atau karena dia membutuhkan buku atau informasi tertentu.

4. Subject of study, yaitu bidang apa yang sedang didalami pengguna. Apakah dia sedang menulis mengenai suatu subjek tertentu yang sangat khusus atau sedikit luas.

5. Level of study, yaitu tingkat pendidikan pengguna. Misalnya kebutuhan mahasiswa S1 tentu berbeda dengan kebutuhan mahasiswa tingkat S2 atau S3.

6. Motivation yaitu sejauh mana keinginan dan antusiasme pengguna dalam memanfaatkan layanan perpustakaan.

Pengguna berkunjung ke perpustakaan karena adanya kebutuhan yang ingin dipenuhi. Menurut Fisher [1998] ada tiga kebutuhan yang sering ditemui pengguna perpustakaan yaitu:

1. Need for information, merupakan suatu kebutuhan akan informasi yang bersifat umum.

2. Need for material and facilities, merupakan kebutuhan untuk mendapatkan buku-buku atau bahan pustaka lain serta kebutuhan fasilitas perpustakaan yang menunjang kegiatan belajar.

3. Need for guidance and support, merupakan kebutuhan untuk mendapatkan bimbingan atau petunjuk yang memudahkan pengguna mendapatkan apa yang diinginkan.

Pemahaman mengenai pengguna mutlak dibutuhkan oleh perpustakaan. Menurut Sulistyo-Basuki [1993], kajian pengguna memiliki 3 tujuan komprehensif yaitu:

1. Analisis kebutuhan; yang dikaji adalah jenis dan sifat informasi yang dicari dan diterima, 
dari titik pandang kuantitatif dan kualitatif.

2. Analisis perilaku informasi; analisis ini menunjukkan bagaimana kebutuhan informasi dipenuhi. Analisis ini menjelaskan konteks jasa dan produk yang disajikan, menjelaskan kondisi yang dihadapi, serta menunjukkan tipe kesiapan dan atau pelatihan untuk pemakai.

Analisis motivasi dan sikap; Kajian ini mencakup nilai yang dinyatakan pengguna, baik diungkapkan secara terbuka atau harapan yang tersembunyi tentang informasi dan aktivitas berkaitan, citra pengguna tentang jasa dan spesialis informasi dan sebagainya. Kajian mengenai hal ini akan mengungkapkan alasan yang dalam mengenai perilaku dan kebutuhan khusus pengguna.

Beragamnya perpustakaan di lingkungan UGM yakni 18 perpustakaan fakultas, 1 perpustakaan Pasca Sarjana, dan 44 perpustakaan pusat studi, magister, lembaga, dan jurusan menyebabkan tidak semua mahasiswa UGM mengambil keputusan untuk menjadi anggota UPU Perpustakaan UGM yang notabene adalah perpustakaan universitas.

Membaca menjadi suatu kegiatan yang termarginalkan dalam aktivitas masyarakat. Kenyataan ini memang cukup memprihatinkan. Tetapi inilah realita sosial yang terjadi. Sebuah realita yang harus dihadapi dan dicari solusinya.

Permasalahan yang dicoba untuk dijawab dalam penelitian ini adalah: Mengapa mahasiswa UGM melakukan keputusan menjadi anggota UPU Perpustakaan dan tidak menjadi anggota UPU Perpustakaan? Faktor-faktor apa yang mempengaruhi keputusan mahasiswa menjadi anggota UPU Perpustakaan UGM? Apakah ada perbedaan signifikan yang dilakukan oleh mahasiswa dalam keputusan keanggotaan UPU Perpustakaan UGM berdasarkan karakteristik pengguna yang meliputi jenis kelamin, tingkat pendidikan, serta program studi?

Variabel indipenden yang mempengaruhi keputusan mahasiswa dalam keanggotaanya di Perpustakaan UGM yakni latar belakang sosial dan lingkungan sosial. Variabel antara dalam penelitian ini yakni motivasi. Variabel dipenden dalam penelitian ini adalah pengambilan keputusan mahasiswa menjadi anggota UPU Perpustakaan UGM yang didefinisikan sebagai pilihan tindakan dalam menentukan untuk menjadi anggota UPU Perpustakaan UGM atau tidak.

Kerangka pemikiran dalam penelitian ini adalah sebagai berikut:

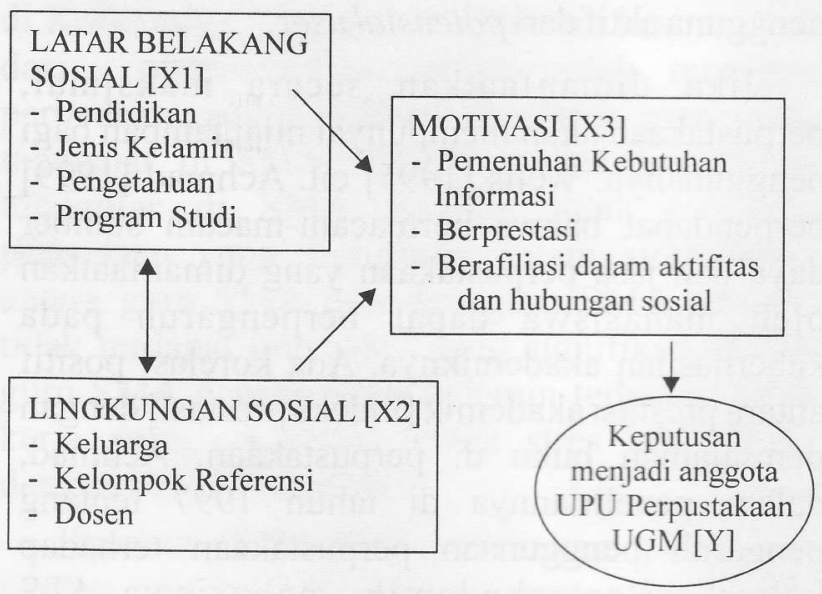

Dari gambar tersebut dapat dijelaskan bahwa latar belakang sosial dan lingkungan sosial akan memberikan motivasi yang kuat bagi mahasiswa untuk menjadi anggota UPU Perpustakaan UGM. Pengambilan keputusan mahasiswa menjadi anggota suatu perpustakaan tidak dapat lepas dari keadaan mahasiswa itu sendiri dan lingkungan dimana mahasiswa tersebut berada. Proses lingkungan sosial yang hidup di sekitar pribadi atau kanak-kanak sangat mempengaruhi pembentukan kepribadian mahasiswa. Keluarga yang menekankan minat baca sejak dini serta intensitas saran dosen untuk menggunakan fasilitas di perpustakaan mendorong mahasiswa untuk melakukan keputusan menjadi anggota perpustakaan. Keputusan mahasiswa untuk menjadi anggota perpustakaan merupakan suatu ekspresi dari sebuah kebutuhan informasi yang dirasakan seseorang akibat tugas yang dikerjakan atau untuk memenuhi rasa ingin tahu. Timbulnya kesenjangan dalam diri manusia akhirnya mendorong seseorang untuk mencari informasi guna mengatasi permasalahan yang dihadapinya.

Hipotesis kerja yang dirumuskan sebagai 
berikut: "Semakin tinggi tingkat pendidikan yang didukung oleh keluarga yang menanamkan minat baca sejak dini serta intensitas saran dosen untuk menggunakan fasilitas perpustakaan memberikan motivasi yang kuat bagi mahasiswa dalam pemenuhan kebutuhan informasi dan berprestasi melalui keputusan untuk menjadi anggota perpustakaan".

\section{CARA PENELITIAN}

Penelitian ini termasuk dalam jenis penelitian campuran antara penelitian kualitatif dan penelitian penjelasan [explanatory research]. Penelitian ini menjelaskan hubungan kausal antara variabel-variabel melalui pengujian hipotesa. Informasi kualitatif pada data kuantitatif dimaksudkan untuk memperkaya data dan lebih memahami fenomena sosial yang diteliti, yakni keputusan mahasiswa menjadi anggota UPU Perpustakaan UGM.

Teknik pengumpulan data yang digunakan adalah kuessioner, wawancara, meneliti dokumen dan hasil penelitian serupa, serta observasi. Pengumpulan data menggunakan metode penelitian survai, yakni metode pengumpulan informasi dari responden dengan menggunakan daftar pertanyaan yang telah terstruktur atau kuesioner.

Populasi dalam penelitian ini adalah keseluruhan responden yang menjadi subyek penelitian yakni pengunjung UPU Perpustakaan UGM baik dari dalam UGM maupun luar UGM. Adapun rata-rata pengunjung harian menurut data statistik tahun 2005 adalah sekitar 529 orang [Unit I dan Unit II]. Penyebaran kuesioner pada awalnya dilakukan pada 130 responden. Setelah dilakukan tabulasi data yang bersumber dari kuesioner maka terdapat 105 kuesioner yang dapat digunakan untuk sumber analisis data, untuk itu dari 105 kuesioner tersebut yang akhirnya dijadikan sampel penelitian. Metode pengambilan sampel yang digunakan adalah dengan cara acak sederhana [simple random sampling/probability sampling], artinya semua elemen memiliki peluang yang sama untuk dipilih menjadi anggota sampel. Sampel yang dipilih adalah pengunjung UPU Perpustakaan
UGM di Perpustakaan Unit 1 Bulaksumur dan Unit 2 Sekip.

Pembahasan mengenai ada atau tidaknya hubungan dan eratnya hubungan antara dua variabel atau lebih satu pengaruh yang signifikan antar variabel, dilakukan dengan menggunakan analisis korelasi multivariat.

Analisa kualitatif yang berisi uraian-uraian deskriptif yang didukung oleh teori-teori yang cukup digunakan untuk memperkuat analisa kuantitatif. Analisa ini digunakan untuk menjelaskan data yang belum terangkum dalam penjelasan kuantitatif, sehingga hasil penelitian lebih berbobot.

\section{HASIL DAN PEMBAHASAN}

A. Hubungan antara Latar Belakang Sosial [X1] dengan Lingkungan Sosial [X2] dan Motivasi [X3]

Perpustakaan perguruan tinggi sebagai salah satu sarana pusat informasi di lingkup perguruan tinggi memiliki peran penting bagi para sivitas akademika. Perpustakaan di perguruan tinggi merupakan center of learning and instruction yang berarti pusat belajar, yang bertugas menyediakan berbagai sumber belajar, mengolahnya supaya dapat dimanfaatkan seoptimal mungkin oleh kalangan sivitas akademika, demi tercapainya tujuan pembelajaran, penelitian dan pengabdian masyarakat.

Bagi mahasiswa, perpustakaan seringkali dimanfaatkan sebagai tempat untuk mendapatkan informasi guna menunjang kegiatan belajar yang bersumber koleksi yang ada. Perpustakaan berada di tengah masyarakat, eksistensi perpustakaan muncul karena kebutuhan masyarakat, serta dipelihara dan dikembangkan oleh masyarakat. Oleh karena itu perpustakaan harus memanfaatkan sumberdaya yang ada semaksimal mungkin, sehingga kebutuhan informasi masyarakat akan dapat terpenuhi.

Mahasiswa sebagai pengguna perpustakaan dapat dibedakan berdasarkan latar belakang 
sosialnya seperti; pendidikan, jenis kelamin, pengetahuan maupun program studi. Dalam menggunakan jasa perpustakaan mahasiswa akan dipengaruhi oleh lingkungan sosial baik lingkungan terdekat mereka seperti keluarga, pengaruh dari kelompok referensi [teman] maupun dosen. Di samping itu dapat pula dikarenakan adanya motivasi dari para mahasiswa itu sendiri seperti pemenuhan kebutuhan informasi, kebutuhan untuk berprestasi maupun berafiliasi.

Hubungan antara latar belakang sosial [X1] dengan lingkungan sosial [X2] ditunjukkan dalam hubungan antara tingkat pendidikan dengan intensitas saran dosen untuk menggunakan perpustakaan.

Tingkat pendidikan adalah suatu tahapan dimana seseorang memperoleh pendidikan yang diperlukannya. Tingkat pendidikan menjadikan pengetahuan, pengalaman, keahlian dan kebutuhan mereka berbeda. Perbedaan ini selanjutnya akan membedakan nilai seseorang di masyarakat. Pendidikan yang dimiliki akan membuka cakrawala berpikir sehingga dia dapat melihat sesuatu yang baik dan sesuai, yang pada akhirnya mendorong seseorang yang mengalami pendidikan akan mengalami interaksi antara kecerdasan, perhatian dan pengalamannya yang kemudian dinyatakan dalam sikap perilaku dan kebiasaannya. Semakin tinggi tingkat pengetahuan individu menyebabkan kerangka pemikiran dan pengalamannya lebih didasarkan pada kenyataan dan alasan rasional.

Sebaliknya semakin rendah tingkat pendidikan semakin sedikit pengetahuan yang dimiliki, sehingga akan mempengaruhi cara berpikir yang cenderung ke arah pragmatis. Dalam hal ini, Soedjito [1984: 17] juga mengungkapkan:

Orang yang berpendidikan rendah, pola pikirnya tradisional yaitu berpikir hanya untuk hari ini saja, sedangkan besok itu urusan nanti. Orang yang berpendidikan tinggi pola pikirnya modern, yakni masa depan itulah yang dipentingkan.

Tingkat pendidikan responden dapat dikategorikan menjadi tiga tingkatan yaitu:
Diploma, Sarjana Strata 1 [S1], dan Pasca Sarjana [S2]. Hasil penelitian menunjukkan bahwa semakin tinggi tingkat pendidikan mahasiswa maka intensitas dosen dalam memberikan saran pada mahasiswa untuk meminjam dan menggunakan fasilitas yang ada di perpustakaan semakin sering.

Dari hasil perhitungan diperoleh nilai $\mathrm{P}<$ 0,05 adalah signifikan. Hal ini berarti ada korelasi [hubungan] antara variabel latar belakang sosial [X1] dengan lingkungan sosial [X2] dengan tingkat korelasi [hubungan] yang rendah karena nilai $r$ jauh dari 1 . Arah korelasi adalah positif yang menunjukkan bahwa apabila latar belakang sosial [X1] meningkat maka meningkat pula lingkungan sosialnya [X2].

Hubungan antara latar belakang sosial [X1] dengan motivasi [X3] dijelaskan pada hubungan antara tingkat pendidikan dengan motivasi mahasiswa menjadi anggota perpustakaan; dan hubungan antara pengetahuan dengan motivasi mahasiswa untuk menjadi anggota perpustakaan

Berdasarkan hasil penelitian dapat ditunjukkan hubungan antara dampak yang dirasakan mahasiswa dengan membacal meminjam buku di perpustakaan dengan motivasi mahasiswa menjadi anggota perpustakaan adalah tinggi. Mayoritas mahasiswa [67,71\%] sangat menyadari dampak yang diperoleh dari membaca/meminjam buku di perpustakaan akan meningkatkan dan menambah pengetahuan mereka sehingga dengan adanya motivasi akan berprestasi inilah yang mendorong minat mereka untuk menjadi anggota perpustakaan.

Dari hasil perhitungan diperoleh nilai $\mathrm{P}<$ 0,05 adalah signifikan. Hal ini berarti ada korelasi [hubungan] antara variabel latar belakang sosial [X1] dengan motivasi [X3] dengan tingkat korelasi [hubungan] yang rendah karena nilai $r$ jauh dari 1. Arah korelasi adalah positif yang menunjukkan bahwa apabila latar belakang sosial [X1] meningkat maka meningkat pula motivasi mahasiswa [X3].

Dalam hal pengambilan keputusan menjadi anggota perpustakaan, mahasiswa sangat dipengaruhi oleh faktor lingkungan sosial yakni 
keluarga, kelompok referensi, dan dosen. Keputusan mahasiswa menjadi anggota perpustakaan juga dipengaruhi oleh motivasi dari mahasiswa tersebut. Motivasi yang ada pada seseorang merupakan kekuatan pendorong yang akan mewujudkan suatu perilaku guna mencapai tujuan dirinya.

Dalam penelitian ini hubungan antara lingkungan sosial [X2] dengan motivasi [X3] ditunjukkan pada hubungan antara peran keluarga dengan motivasi serta hubungan antara intensitas saran dosen untuk meminjam buku dengan motivasi menjadi anggota perpustakaan.

Dalam hal pengambilan keputusan menjadi anggota perpustakaan, mahasiswa sangat dipengaruhi oleh faktor lingkungan sosial yakni:

1) Keluarga; Institusi keluarga berperan besar dalam keputusan mahasiswa menjadi anggota perpustakaan. Beberapa kegiatan dapat dilakukan orang tua bersama anak seperti bermain dengan bacaan bersama anak, berkunjung ke perpustakaan, mengusahakan perpustakaan keluarga dan memberikan hadiah buku. Kegiatankegiatan ini mempunyai pengaruh yang positif dalam diri mahasiswa untuk mencintai buku dan mengunjungi perpustakaan.

2) Kelompok Referensi; Kelompok referensi adalah kelompok sosial yang mempengaruhi pendapat dalam keputusannya dan sering dijadikan pedoman. Peran kelompokkelompok tertentu merupakan model keputusan dalam mempengaruhi perilaku seseorang. Kelompok semacam ini disebut kelompok referensi [reference group]. Reference group adalah kelompok sosial yang dijadikan sebagai perbandingan atau contoh bagi seseorang yang bukan sebagai anggotanya, kemudian seseorang yang bersangkutan melakukan identifikasi dirinya sebagaimana kelompok contoh tersebut.

3) Dosen; Dosen adalah orang yang juga berperan dalam mendorong mahasiswa datang ke perpustakaan. Dalam hal ini dosen mampu memperluas gagasan mahasiswa secara bebas dan menghasilkan pikiran- pikiran positif.

Selain karena faktor lingkungan sosial, keputusan mahasiswa menjadi anggota perpustakaan juga dipengaruhi oleh motivasi dari mahasiswa tersebut. Motivasi yang ada pada seseorang merupakan kekuatan pendorong yang akan mewujudkan suatu perilaku guna mencapai tujuan kepuasaan dirinya. Motivasi orang tergantung pada kekuatan motifnya. Motif yang dimaksud dalam hal ini adalah kebutuhan, keinginan, dorongan atau gerak hati dalam diri individu

Hal penting yang perlu diformulasikan adalah kesamaan motivasi antara pengguna [user] dengan pustakawan dalam meningkatkan minat baca kaitannya dengan keanggotaan perpustakaan. Seperti diketahui, manusia dalam melakukan suatu aktivitas akan berhasil dengan baik apabila dilandasi motivasi-motivasi tertentu yang tertanam dalam dirinya. Motivasi adalah stimulus untuk mendorong pemenuhan kebutuhan masing-masing individu.

Motivasi adalah keinginan yang terdapat pada diri seseorang individu yang merangsang untuk melakukan tindakan-tindakan. Motivasi itu tampak dalam dua segi yang berbeda. Dari segi aktif atau dinamis, motivasi tampak sebagai suatu usaha positif dalam menggerakkan daya dan potensi belajar, agar berhasil mencapai dan mewujudkan tujuan yang telah ditetapkan sebelumnya.. Dari segi pasif atau statis, motivasi akan tampak sebagai suatu kebutuhan dan sekaligus sebagai suatu perangsang untuk dapat menggerakkan potensi manusia ke arah yang diinginkannya.

Mengunjungi perpustakaan dengan tujuan untuk mendapatkan banyak ilmu pengetahuan akan menyebabkan motivasi seseorang menjadi rendah. Ia akan terbebani dengan berbagai macam target jangka pendek. Berbeda ketika ia merasa bahwa berkunjung ke perpustakaan adalah sebuah petualangan, bermain, dan rekreasi dengan dunia buku. Secara tidak langsung ia merasa bahwa belajar di perpustakaan adalah aktivitas yang menyenangkan. [Awaludin, 2003] Teori kepuasan memusatkan perhatian pada faktor-faktor di dalam individu yang mendorong, 
mengarahkan, mempertahankan, dan menghentikan perilaku, yakni fisiologis, keamanan dan keselamatan, rasa memiliki dan kasih sayang, penghargaan dan yang terakhir aktualisasi diri.

Menurut Maslow, manusia akan didorong untuk memenuhi kebutuhan yang paling kuat sesuai waktu, keadaan dan pengalaman yang bersangkutan mengikuti suatu hirarki. Dalam tingkatan ini, kebutuhan pertama yang harus dipenuhi terlebih dahulu adalah kebutuhan fisiologi. Setelah kebutuhan pertama dipuaskan, kebutuhan yang lebih tinggi berikutnya akan menjadi kebutuhan utama, yaitu kebutuhan akan keamanan dan rasa aman. Kebutuhan ketiga akan muncul setelah kebutuhan kedua terpuaskan. Proses ini berjalan terus sampai terpenuhinya kebutuhan aktualisasi diri.

Kebutuhan aktualisasi diri [self actualization] adalah kebutuhan dengan menggunakan kecakapan, kemampuan, ketrampilan dan potensi optimal untuk mencapai prestasi yang sangat memuaskan atau sulit dicapai orang lain. Inilah kebutuhan puncak paling tinggi, sehingga seseorang ingin mempertahankan prestasinya secara optimal. Model Mc Clelland [1961] sangat menekankan perhatian pada prestasi [achievement] serta kebutuhan berinteraksi dengan orang lain [Need for Affiliation] Kebutuhan ini menjadi daya penggerak yang akan memotivasi semangat belajar mahasiswa.

Minat seseorang terhadap sesuatu adalah kecenderungan hati yang tinggi, gairah dan keinginan seseorang terhadap sesuatu. Minat baca seseorang dapat diartikan sebagai kecenderungan hati yang tinggi orang tersebut kepada suatu sumber bacaan tertentu. Sedangkan budaya adalah pikiran atau akal budi yang tercermin di dalam pola pikir sikap, ucapan dan tindakan seseorang di dalam hidupnya. Budaya diawali dari sesuatu yang sering atau biasa dilakukan sehingga akhirnya menjadi suatu kebiasaan atau budaya. Budaya baca seseorang adalah suatu sikap dan tindakan atau perbuatan untuk membaca yang dilakukan secara teratur dan berkelanjutan. Seseorang yang mempunyai budaya baca adalah bahwa orang tersebut telah terbiasa dalam waktu yang lama di dalam hidupnya selalu menggunakan sebagian waktunya untuk membaca. [Sutarno NS, 2001]

Memupuk minat baca merupakan proses pelatihan yang dilakukan secara terus menerus. Oleh sebab itu permulaan pelatihan membaca harus dilakukan sejak anak usia dini, tepatnya ketika anak duduk di bangku Sekolah Dasar. Dengan demikian, peran orang tua dan guru sangat besar terhadap penumbuhan minat dan kebiasaan membaca. Mary Leonhardt [1990] telah menemukan resep bahwa anak yang gemar membaca tidak datang dari anak itu sendiri tetapi anak yang gemar membaca ternyata mempunyai orang tua dan guru yang mampu membimbing anak-anaknya untuk membaca. Penyebabnya adalah bahwa membaca itu harus bersifat kesenangan [fun] dan bukan paksaan atau tugas [task]. Lebih lanjut dikatakan bahwa anak yang biasa membaca atau anak yang gemar membaca terbukti jauh lebih pandai IQ dan EQ-nya daripada teman-temannya yang kurang membaca. Anak yang membaca mempunyai penalaran dan tingkat kecerdasan yang jauh di atas rata-rata kelas. Sementara itu tingkatan emosionalnya sangat seimbang. Bahkan dalam melakukan "problem solving" rata-rata lebih logis pemikirannya, disertai dengan bahasa yang runtut dan santun.

Pendorong bagi bangkitnya minat baca ialah kemampuan membaca, dan pendorong bagi berseminya budaya baca adalah kebiasaan membaca, sedangkan kebiasaan membaca terpelihara dengan tersedianya bahan bacaan yang baik, menarik, memadai, baik jenis, jumlah, maupun mutunya. Inilah formula secara ringkas untuk pengembangan minat dan budaya baca. Dari rumus tersebut tersirat tentang perlunya minat baca itu dibangkitkan sejak usia dini, dimulai dengan perkenalan dengan bentukbentuk huruf dan angka pada masa pendidikan prasekolah hingga mantapnya penguasaan baca tulis hitung pada awal pendidikan di Sekolah Dasar. Perlu dicatat bahwa dalam dunia belajar modern setiap anak mulai berkenalan dengan bentuk-bentuk huruf dan tanda-tanda yang mempunyai arti tertentu. Akan lebih baik lagi kalau anak tersebut mulai menyadari bahwa 
rangkaian huruf-huruf ini mempunyai sesuatu cerita yang menarik, maka tentu akan mendorongnya untuk berkenalan dengan katakata dan selanjutnya berniat untuk dapat membaca [Fuad Hassan, 2001]

Demikianlah perkembangan anak sejak usia dini sudah mulai mengenal berbagai bentuk huruf dan tanda yang kemudian diketahuinya memiliki makna. Oleh karenanya perlu membangkitkan rasa ingin tahu [curiousity] yang kuat pada diri seorang anak. Dengan begitu sejak usia dini pula perlu sudah tersedia bahan bacaan yang menarik, baik untuk dibacakan kepada anak atau dibaca sendiri olehnya. Bangkitnya minat baca juga terdorong sejauh mana perkenalan anak terhadap buku.

Hasil penelitian menunjukkan bahwa peranan keluarga dalam menekankan pentingnya membaca mampu menimbulkan motivasi yang kuat bagi anak [mahasiswa] untuk tertarik menjadi anggota perpustakaan.

Dari hasil perhitungan diperoleh nilai $\mathrm{P}<$ 0,05 adalah signifikan. Hal ini berarti ada korelasi [hubungan] antara variabel lingkungan sosial [X2] dengan motivasi [X3] dengan tingkat korelasi [hubungan] yang rendah karena nilai $\mathrm{r}$ jauh dari 1. Arah korelasi adalah positif yang menunjukkan bahwa apabila lingkungan sosial [X2] meningkat maka meningkat pula motivasinya [X3].

Hal ini berarti secara meyakinkan terdapat pengaruh intensitas saran dosen terhadap motivasi menjadi anggota perpustakaan.

Dalam penelitian ini tingkat kemantapan menjadi anggota dijadikan sebagai indikator keputusan menjadi anggota perpustakaan. Tingkat kemantapan menjadi anggota UPU Perpustakaan UGM dalam penelitian ini dikategorikan dalam 3 (tiga) tingkatan yakni rendah, sedang dan tinggi. Adapun pengkategorian tingkat kemantapan menjadi anggota sebagai indikator keputusan menjadi anggota perpustakaan keputusan menjadi anggota UPU Perpustakan UGM adalah sebagai berikut:

Tingkat kemantapan rendah, artinya ada kecenderungan mahasiswa tidak menganggap penting peran perpustakaan universitas yang berakibat mahasiswa tidak berminat menjadi anggota perpustakaan. Kualitas layanan yang rendah, tidak tersedianya koleksi yang lengkap dan memadai, serta sarana pendukung yang minim merupakan faktor utama penyebab kemantapan mahasiswa dalam memutuskan untuk menjadi anggota perpustakaan. Faktor budaya yakni budaya lisan berakar sangat kuat dengan masyarakat Indonesia. Masyarakat lebih suka mencari suatu informasi dengan bertanya kepada orang lain daripada harus membaca buku. Mahasiswa juga beranggapan bahwa keputusan menjadi anggota perpustakaan adalah bukan keputusan penting dan tidak menjadi kebutuhan utama mahasiswa.

Tingkat kemantapan sedang, artinya ada kecenderungan mahasiswa menganggap penting peran perpustakaan universitas bagi kelangsungan studi. Tetapi keputusan mahasiswa menjadi anggota perpustakaan bukan suatu kewajiban yang harus dilakukan oleh setiap mahasiswa. Intensitas saran dosen untuk menggunakan fasilitas di perpustakaan mendorong mahasiswa untuk meningkatkan kemantapannya dalam melakukan keputusan menjadi anggota perpustakaan. Selain itu mahasiswa tersebut memang berasal dari keluarga yang menekankan minat baca sejak dini. Tersedianya perpustakaan fakultas, perpustakaan jurusan, perpustakaan program studi, serta perpustakaan lembaga penelitian dan perpustakaan pusat studi yang berada di lingkungan UGM memungkinkan mahasiswa mempunyai beberapa alternatif pilihan dalam mengambil keputusan menjadi anggota perpustakaan. Ada kecenderungan mahasiswa membandingkan koleksi dan berbagai fasilitas yang tersedia di masing-masing perpustakaan. Mahasiswa akan memutuskan untuk menjadi anggota UPU Perpustakaan UGM apabila mereka merasa informasi yang dicarinya tersedia dan kebutuhan mereka terpenuhi. Apabila kebutuhan tersebut tidak terpenuhi di UPU Perpustakaan UGM, mahasiswa cenderung memilih perpustakaan fakultas atau perpustakaan jurusan sebagai tujuannya dalam membantu kelancaran studi mereka. Inilah yang menjadi 
tantangan UPU Perpustakaan UGM untuk bisa "bersaing" dengan perpustakaan fakultas, perpustakaan jurusan, serta beberapa perpustakaan penelitian yang ada di lingkungan UGM. Mereka yang memiliki daya beli yang lebih besar dan mengutamakan buku-buku terkini lebih tertarik mencari buku yang ada di toko buku. Tak akan terlalu sulit bagi mereka untuk mencari buku yang lebih up date dibandingkan dengan yang ada di perpustakaan. Hal inilah yang belum bisa ditawarkan oleh perpustakaan kepada pengunjungnya.

Tingkat kemantapan tinggi, artinya ada kecenderungan dari mahasiswa menganggap perpustakaan universitas adalah sangat penting untuk membantu kelancaran studi mereka sehingga mahasiswa mengambil keputusan untuk menjadi anggota perpustakaan. Tingkat kemantapan tinggi sangat dipengaruhi oleh motivasi dari dalam diri mahasiswa. Motivasi yang ada pada mahasiswa merupakan kekuatan pendorong yang akan mewujudkan suatu perilăku guna mencapai tujuan kepuasaan dirinya. Motivasi seseorang tergantung pada kekuatan motifnya yakni kebutuhan, keinginan, dorongan atau gerak hati dalam diri individu. Keputusan mahasiswa untuk menjadi anggota perpustakaan merupakan suatu ekspresi dari sebuah kebutuhan informasi yang dirasakan seseorang akibat tugas yang dikerjakan atau untuk memenuhi rasa ingin tahu. Kebutuhan aktualisasi diri [self actualization] adalah kebutuhan dengan menggunakan kecakapan, kemampuan, ketrampilan dan potensi optimal untuk mencapai prestasi yang sangat memuaskan atau sulit dicapai orang lain. Inilah kebutuhan puncak paling tinggi, sehingga mahasiswa ingin mempertahankan prestasinya secara optimal. Kebutuhan untuk berprestasi inilah yang menjadi daya penggerak yang akan memotivasi semangat belajar mahasiswa.

Secara mayoritas mahasiswa memiliki tingkat kemantapan "sedang" untuk menjadi anggota perpustakaan, yaitu secara statistik $65,7 \%$. Hal ini menunjukkan bahwa minat mahasiswa cukup bagus untuk berkeputusan menjadi anggota perpustakaan.
Hubungan antara lingkungan sosial dengan keputusan untuk menjadi anggota UPU Perpustakaan UGM dapat dilihat pada hubungan antara peran keluarga dengan keputusan menjadi anggota perpustakaan

Dari hasil perhitungan diperoleh nilai $\mathrm{P}<$ 0,05 adalah signifikan. Hal ini berarti ada korelasi [hubungan] antara variabel lingkungan sosial [X2] dengan keputusan mahasiswa menjadi anggota UPU Perpustkaan UGM [Y] dengan tingkat korelasi [hubungan] yang rendah karena nilai $r$ jauh dari 1 . Arah korelasi adalah positif yang menunjukkan apabila lingkungan sosial [X2] meningkat maka meningkat pula keputusan mahasiswa menjadi anggota UPU Perpustakaan UGM [Y].

\section{B. Hubungan antara Lingkungan Sosial [X2] dan Motivasi [X3] dengan Keputusan Mahasiswa menjadi Anggota Perpustakaan [Y]}

Proses lingkungan sosial yang hidup di sekitar pribadi atau kanak-kanak sangat mempengaruhi pembentukan kepribadian mahasiswa. Keluarga yang menekankan minat baca sejak dini serta intensitas saran dosen untuk menggunakan fasilitas di perpustakaan mendorong mahasiswa untuk melakukan keputusan menjadi anggota perpustakaan.

1. Hubungan antara motivasi berprestasi dengan intensitas kunjungan ke perpustakaan

Dari hasil perhitungan diperoleh nilai $\mathrm{P}<$ 0,05 adalah signifikan. Hal ini berarti ada korelasi [hubungan] antara variabel motivasi [X3] dengan keputusan mahasiswa menjadi anggota UPU Perpustakaan UGM [Y] dengan tingkat korelasi [hubungan] yang tinggi karena nilai $r$ mendekati 1 . Arah korelasi adalah positif yang menunjukkan bahwa apabila motivasi [X3] meningkat maka meningkat pula keputusan mahasiswa menjadi anggota UPU Perpustkaan UGM [Y].

Mahasiswa yang memiliki motivasi berprestasi tinggi dengan menyadari bahwa 
dengan menggunakan jasa perpustakaan maka dapat mempengaruhi peningkatan Indeks Prestasi [IP] akan melakukan kunjungan secara aktif di perpustakaan kurang lebih 2 sampai 3 kali dalam seminggu, mereka lebih sering mengunjungi perpustakaan dibanding dengan mahasiswa yang menilai bahwa dengan menggunakan jasa perpustakaan tidak akan mempengaruhi Indeks Prestasi [IP] mahasiswa.

2. Hubungan antara motivasi menjadi anggota perpustakaan dengan pandangan tentang prosedur menjadi anggota perpustakaan

Dari hasil perhitungan diperoleh nilai $\mathrm{P}<$ 0,05 adalah signifikan. Hal ini berarti ada korelasi [hubungan] antara variabel motivasi [X3] dengan keputusan mahasiswa menjadi anggota UPU Perpustkaan UGM [Y] dengan tingkat korelasi [hubungan] yang tinggi karena nilai $\mathrm{r}$ mendekati 1 . Arah korelasi adalah positif yang menunjukkan bahwa apabila motivasi [X3] meningkat maka meningkat pula keputusan mahasiswa menjadi anggota UPU Perpustkaan UGM [Y].

Berdasarkan penjelasan tersebut dapat disimpulkan bahwa minat mahasiswa untuk menjadi anggota perpustakaan dipengaruhi oleh kemudahan prosedur teknis untuk menjadi anggota perpustakaan.

Motivasi yang kuat dari dalam diri mahasiswa harus didukung oleh penyediaan bahan bacaan yang bermutu dan relevan/sesuai dengan kebutuhan pemakai perpustakaan harus diperhatikan oleh perpustakaan. Karena saat ini masih ditemui bahan-bahan bacaan yang dimiliki perpustakaan kurang sesuai dengan kebutuhan mahasiswa.

\section{Pengaruh Latar Belakang Sosial [X1], Lingkungan Sosial [X2], dan Motivasi [X3] terhadap Keputusan Mahasiswa menjadi Anggota UPU Perpustakaan UGM [Y]}

Koleksi bahan pustaka yang memadai, baik mengenai jumlah, jenis, dan mutunya, yang tersusun rapi, dengan sistem pengolahan serta kemudahan akses atau temu kembali informasi merupakan salah satu kunci keberhasilan perpustakaan. Oleh sebab itu perpustakaan perlu memiliki koleksi bahan pustaka yang relatif lengkap sesuai dengan visi, misi, perencanaan strategi, kebijakan, dan tujuannya. Koleksi bahan pustaka yang baik adalah dapat memenuhi selera, keinginan dan kebutuhan pembaca. Kekuatan koleksi bahan pustaka itu merupakan daya tarik bagi pemakai, sehingga makin banyak dan lengkap koleksi bahan pustaka yang dibaca dan dipinjam, akan semakin ramai perpustakaan dikunjungi mahasiswa dan makin tinggi intensitas sirkulasi buku. Akhirnya makin besar pula proses transfer informasi [transfer of information] dan di sini perpustakaan berfungsi sebagai media atau alat serta jembatan perantara antara sumber informasi dengan masyarakat pemakai.

Respon dan perhatian mahasiswa terhadap perpustakaan yang relatif rendah mungkin disebabkan oleh beberapa faktor. Misalnya ketidaktahuan atau kekurangtahuan mahasiswa di mana letak/lokasi perpustakaan, apa kegunaan perpustakaan, siapa saja yang dapat dan boleh ke perpustakaan, bagaimana cara menjadi anggota perpustakaan, apa saja persyaratan untuk menjadi anggota, bahan pustaka apa saja yang ada di perpustakaan, apakah untuk menjadi anggota harus membayar, dan lain sebagainya. Faktorfaktor tersebut yang menjadikan masyarakat universitas yakni mahasiswa kurang tinggi dalam merespon dan memperhatikan perpustakaan.

Setelah mahasiswa mengerti dan menyadari bahwa keberadaan perpustakaan universitas adalah untuk mahasiswa, tentu diharapkan respon dan perhatian mereka adakan dapat berkembang. Untuk mengembangkan respon dan perhatian masyarakat universitas perlu dilakukan pendekatan. Antara lain pendekatan sosial, yakni upaya yang dilakukan perpustakaan agar mahasiswa memahami dan mengerti tentang perlu dan pentingnya menambah wawasan dan pengetahuan yang dibutuhkan sehari-hari, dan hal itu diantaranya dapat ditemukan di perpustakaan. Kemudian pendekatan kultural, maksudnya adalah bahwa pada umumnya masyarakat Indonesia masih memiliki budaya 
lisan atau budaya tutur yang kuat dan melekat di dalam adat kebiasaan mereka. Budaya lisan itu secara sedikit demi sedikit perlu diubah dengan mengembangkan budaya tulis, yaitu membiasakan diri dengan membaca bacaan yang bermanfaat.

Secara bertahap dicoba untuk memanfaatkan waktu luang dengan membaca bahan pustaka, baik yang ada di rumah maupun perpustakaan. Mengubah suatu budaya yang sudah mengakar dalam ke tengah-tengah masyarakat bukan hal yang mudah. Perubahan itu memerlukan kesabaran, keuletan, dan perlu waktu yang panjang. Tetapi jika ingin maju dan berkembang maka hal itu mau tidak mau harus dilakukan.

Kehadiran anggota masyarakat universitas yakni mahasiswa dan pemakai yang lain menjadi salah satu kunci keberhasilan perpustakaan universitas. Untuk menjadikan mereka sebagai "segmen pasar" layanan merupakan tanggung jawab perpustakaan. Masyarakat baru mau ke perpustakaan jika mereka: [1] tahu arti manfaatnya, [2] mereka membutuhkan sesuatu di perpustakaan, [3] tertarik dengan perpustakaan, [4] merasa senang dengan perpustakaan, [5] dilayani dengan baik

Sumber daya perpustakaan yang mencakup segala sesuatu yang menjadi bagian atau unsur penyelenggaraan kegiatan perpustakaan, seperti gedung, sumber daya manusia, koleksi bahan pustaka, sarana prasarana dan dana merupakan kekuatan atau potensi untuk dibina dan dikembangkan di perpustakaan. Semua faktor atau unsur tersebut dapat menjadi sebuah kekuatan dan potensi apabila kondisinya memadai dan dapat dimanfaatkan secara maksimal. Sebaliknya unsur-unsur tersebut akan merupakan titik-titik kelemahan manakala dalam keadaan kurang memadai dan serba terbatas. Untuk mengubah faktor-faktor negatif seperti kelemahan menjadi unsur yang positif yakni sebuah potensi atau kekuatan, bukan hal yang mudah dan sederhana. Sebab untuk melakukan perubahan dibutuhkan semangat dan kerja keras serta melibatkan semua unsur dalam perpustakaan.

Apabila perpustakaan telah siap secara intern dalam menyajikan informasi kepada pengguna, otomatis kebutuhan mahasiswa menjadi anggota perpustakaan menjadi tinggi, dan mahasiswa benar-benar memperoleh nilai tambah atas keberadaan perpustakaan.

Latar belakang sosial merupakan suatu kemampuan yang melekat pada diri seseorang yang dapat bersifat material maupun sosial yang dapat menunjukkan kualitas seseorang. Latar belakang sosial yang diduga memberikan pengaruh terhadap keputusan mahasiswa untuk menjadi anggota perpustakaan meliputi: tingkat pendidikan, program studi, jenis kelamin, dan pengetahuan.

Ada perbedaan keputusan mahasiswa menjadi anggota UPU Perpustakaan UGM berdasarkan tingkat pendidikan. Hal ini berdasarkan perhitungan diperoleh hasil analisis Chi Square dapat ditunjukkan bahwa dengan tingkat kepercayaan $=5 \%, \mathrm{df}=4$ diperoleh nilai X2 hitung sebesar 15,888 dan X2 tabel sebesar 9,49. Hal ini menunjukkan bahwa X2 hitung $>$ X2 tabel, berarti hipotesa nihil [Ho] ditolak dan menerima hipotesa alternatif [Ha].

Tidak ada perbedaan keputusan mahasiswa menjadi anggota UPU Perpustakaan UGM berdasarkan jenis kelamin. Hal ini berdasarkan perhitungan diperoleh hasil analisis Chi Square dengan tingkat kepercayaan $=5 \%$, df $=2$ diperoleh nilai X2 hitung sebesar 0,621 dan X2 tabel sebesar 5,99. Hal ini menunjukkan bahwa $\mathrm{X} 2$ hitung < X2 tabel, berarti hipotesa nihil [Ho] diterima dan menolak hipotesa alternatif [Ha].

Tidak ada perbedaan keputusan mahasiswa menjadi anggota UPU Perpustakaan UGM berdasarkan program studi. Hal ini berdasarkan perhitungan diperoleh hasil analisis Chi Square dapat ditunjukkan bahwa dengan tingkat kepercayaan $=5 \%$, df $=2$ diperoleh nilai X2 hitung sebesar 1,419 dan X2 tabel sebesar 5,99. Hal ini menunjukkan bahwa X2 hitung $<$ X2 tabel, berarti hipotesa nihil [Ho] diterima dan menolak hipotesa alternatif [Ha].

Hubungan antara latar belakang sosial, lingkungan sosial dan motivasi terhadap keputusan mahasiswa menjadi anggota UPU 
Perpustakan UGM dengan menggunakan alat analisis Regresi Linier Berganda dengan hasil sebagai berikut:

\section{1) Latar Belakang Sosial}

Latar belakang sosial yang terdiri dári indikator pendidikan, jenis kelamin, program studi dan pengetahuan memiliki pengaruh yang positif terhadap keputusan mahasiswa menjadi anggota UPU Perpustakaan UGM. Dimana apabila latar belakang sosial meningkat sebesar 1 satuan maka akan meningkatkan keputusan mahasiswa menjadi anggota UPU Perpustakaan UGM sebesar 0,438 satuan dengan asumsi variabel bebas lainnya adalah tetap [cateris paribus].

\section{2) Lingkungan Sosial}

Lingkungan sosial meningkat sebesar 1 satuan maka akan meningkatkan keputusan mahasiswa menjadi anggota UPU Perpustakaan UGM sebesar 0,152 satuan dengan asumsi variabel bebas lainnya adalah tetap [cateris paribus].

\section{3) Motivasi}

Motivasi akan memiliki pengaruh yang positif terhadap keputusan menjadi anggota UPU Perpustakaan UGM. Dimana apabila motivasi meningkat sebesar 1 satuan maka akan meningkatkan keputusan mahasiswa menjadi anggota UPU Perpustakaan UGM sebesar 1,899 satuan dengan asumsi variabel bebas lainnya adalah tetap [cateris paribus].

Uji koefisien determinasi (adjusted R2) yang tidak lain merupakan uji ketepatan (goodness of fit) ditujukan untuk mengukur ketepatan total variabel terikat terhadap variasi nilai variabelvariabel penjelasnya.

Berdasarkan hasil analisis diperoleh nilai koefisien determinasi atau R2 $=0,520$ hal tersebut menunjukkan bahwa variabel bebas yakni latar belakang sosial (X1), lingkungan sosial (X2) dan motivasi (X3) secara bersamasama mempengaruhi variabel terikat yakni keputusan mahasiswa untuk menjadi anggota UPU Perpustakaan UGM sebesar 52\% sedangkan $48 \%$ dipengaruhi oleh variabel lain yang tidak dilibatkan dalam penelitian ini.

Uji residual merupakan pengujian hipotesa terhadap pengaruh latar belakang sosial, lingkungan sosial dan motivasi terhadap keputusan mahasiswa menjadi anggota UPU Perpustakaan UGM yang akan dijelaskan sebagai berikut:

\section{Uji $t$}

Berdasarkan pengujian hipotesa secara parsial dengan uji t tersebut dapat disimpulkan pula bahwa variabel yang paling dominan berpengaruh terhadap keputusan mahasiswa untuk menjadi anggota UPU Perpustakaan UGM adalah motivasi (X3) hal ini ditunjukkan dari nilai thitung yang terbesar yakni 7,342.

\section{UjiF}

Uji $\mathrm{F}$ dimaksudkan untuk menguji secara keseluruhan/serentak dari variabel independent terhadap variabel dependent atau dengan kata lain uji ini dilakukan untuk mengetahui signifikansi model secara keseluruhan.

Hasil penelitian menunjukkan bahwa $\mathrm{HO}$ ditolak dan $\mathrm{Ha}$ diterima yang berarti terdapat pengaruh yang signifikan antara latar belakang sosial (X1), lingkungan sosial (X2) dan motivasi (X3) secara bersama-sama terhadap keputusan mahasiswa menjadi anggota UPU Perpustakaan UGM, dimana F hitung $(36,505)>\mathrm{F}$ tabel $(3,07)$ dan signifikasi $(p)<0,05$

\section{Penutup}

\section{A. Kesimpulan}

Perpustakaan merupakan sumber informasi bagi mahasiswa di perguruan tinggi. Keputusan mahasiswa untuk menjadi anggota perpustakaan merupakan ekspresi kebutuhan informasi. Beragamnya perpustakaan di lingkungan UGM seperti perpustakaan fakultas, perpustakaan jurusan, serta perpustakaan pusat studi dan perpustakaan lembaga penelitian menyebabkan tidak semua mahasiswa mengambil keputusan untuk menjadi anggota perpustakaan universitas.

Mahasiswa yang memutuskan untuk tidak aktif menjadi anggota perpustakaan dikarenakan 
berbagai alasan seperti: koleksi pustaka yang kurang lengkap dan lebih bersifat umum, ruang perpustakaan yang tidak nyaman karena belum dilengkapi dengan alat pendingin ruangan $[\mathrm{AC}]$ mahalnya biaya aktivasi untuk menjadi anggota UPU Perpustakaan UGM yakni sebesar Rp $15.000,00$ [lima belas ribu rupiah], prosedur yang dirasa berbelit-belit serta stigma tentang layanan perpustakaan yang ditunjukkan oleh pegawai yang kurang ramah. Mahasiswa yang tidak menjadi anggota perpustakaan memanfaatkan jasa perpustakaan untuk membaca buku-buku referensi, menggunakan internet, atau sebagai tempat janjian untuk bertemu teman. Mereka yang memiliki daya beli yang lebih besar dan mengutamakan buku-buku terkini lebih tertarik mencari buku yang ada di toko buku. Tak akan terlalu sulit bagi mereka untuk mencari buku yang lebih up date dibandingkan dengan yang ada di perpustakaan. Hal inilah yang belum bisa ditawarkan oleh perpustakaan kepada pengunjungnya.

Rèspon dan perhatian mahasiswa terhadap perpustakaan relatif belum tinggi karena beberapa faktor, misalnya ketidaktahuan atau kekurangtahuan mahasiswa tentang lokasi perpustakaan; apa kegunaan perpustakaan; siapa saja yang boleh ke perpustakaan; bagaimana cara menjadi anggota perpustakaan; apa saja persyaratan untuk menjadi anggota; bahan pustaka apa saja yang ada di perpustakaan; apakah untuk menjadi anggota harus membayar; dan lain sebagainya.

Setelah melakukan penelitian tentang keputusan mahasiswa pengunjung perpustakaan menjadi anggota UPU Perpustakaan UGM, maka dapat disimpulkan bahwa faktor latar belakang sosial, lingkungan sosial, dan motivasi memang memiliki pengaruh besar dalam keputusan menjadi anggota UPU Perpustakaan UGM.

Mahasiswa yang sering disarankan dosen untuk menggunakan jasa perpustakaan seperti membaca, mereview, dan meminjam buku di perpustakaan menilai bahwa motivasi untuk pemenuhan kebutuhan informasi yang diperlukan dapat terpenuhi. Seringnya dosen memotivasi mahasiswanya untuk membaca atau meminjam buku di perpustakaan baik dalam rangka pemenuhan tugas kuliah maupun pemenuhan kebutuhan informasi lain mendorong mahasiswa mau menjadi anggota perpustakaan.

Keluarga yang menekankan pentingnya membaca pada anak [mahasiswa] secara mayoritas memberikan dampak melakukan keputusan untuk menjadi anggota UPU Perpustakaan UGM. Hal tersebut menunjukkan bahwa mahasiswa mendapatkan pemahaman arti penting membaca atau telah ditanamkan budaya membaca oleh orang tua sejak dini.

Motivasi berprestasi pada diri mahasiswa merupakan dorongan yang sangat wajar terjadi selama mahasiswa menempuh kegiatan belajar. Keinginan mahasiswa untuk memiliki prestasi yang baik dapat dicapai dengan beberapa cara seperti: aktif mengikuti kegiatan perkuliahan, tekun belajar, selalu menambah wawasan dengan mengikuti perkembangan informasi dan pengetahuan serta gemar membaca. Motivasi tersebut mendorong mahasiswa untuk aktif mengunjungi perpustakaan. Mahasiswa yang memiliki motivasi berprestasi tinggi menyadari bahwa jasa perpustakaan dapat mempengaruhi peningkatan Indeks Prestasi [IP] dan mereka melakukan kunjungan ke perpustakaan secara aktif kurang lebih 2 sampai 3 kali seminggu.

Terdapat perbedaan tingkat kemantapan dalam pengambilan keputusan untuk menjadi anggota UPU Perpustakaan UGM berdasarkan tingkat pendidikan mahasiswa dimana semakin tinggi jenjang pendidikannya semakin tinggi pula tingkat keputusan untuk menjadi anggota perpustakaan.

Kesimpulan akhir yang dapat diambil dari penelitian ini sesuai dengan hipotesis yang dikemukakan peneliti yakni semakin tinggi tingkat pendidikan yang didukung oleh keluarga yang menanamkan minat baca sejak dini serta intensitas saran dosen untuk menggunakan fasilitas perpustakaan memberikan motivasi yang kuat bagi mahasiswa dalam pemenuhan kebutuhan informasi dan berprestasi melalui keanggotaan perpustakaan 


\section{B. Saran}

Saran yang bisa disampaikan dalam penelitian ini adalah:

Pertama, bahan pustaka yang memadai, dalam jumlah, jenis, dan mutunya, yang tersusủn rapi, dengan sistem pengolahan serta kemudahan akses atau temu kembali informasi merupakan kunci keberhasilan perpustakaan. Perpustakaan perlu memiliki bahan pustaka yang relatif lengkap sesuai dengan visi, misi, perencanaan strategi, kebijakan, dan tujuannya. Kekuatan koleksi bahan pustaka itu merupakan daya tarik bagi pemakai, sehingga makin banyak dan lengkap bahan pustaka yang dibaca dan dipinjam, akan semakin banyak pengunjung dan makin tinggi intensitas sirkulasi buku. Akhirnya makin besar pula proses transfer informasi [transfer of information] dan di sini perpustakaan berfungsi sebagai media atau alat serta jembatan perantara antara sumber informasi dengan masyarakat pemakai.

Kedua, perpustakaan haruslah menjadi tempat yang menyenangkan dan menggugah minat pengunjung. Tentu saja, dibutuhkan ruangan yang luas, bersih, teratur, nyaman dan atmosfer yang mendukung segala aktivitas pengunjung yang berkaitan dengan dunia akademis.

Ketiga, tidak populisnya Perpustakaan Universitas berakibat minimalnya jumlah mahasiswa UGM yang menjadi anggota UPU Perpustakaan UGM dan ini dapat dikategorikan sebagai kurangnya sosialisasi oleh perpustakaan. Pembenahan demi pembenahan hendaknya terus dilakukan agar peran yang diemban perpustakaan bisa terwujud dengan optimal. Profesionalitas pustakawan juga perlu terus dikembangkan agar pelayanan yang diberikan dapat optimal dan sesuai dengan harapan.

\section{DAFTAR PUSTAKA}

Effendi, Sofian dan Masri Singarimbun. 1989. Metode Penelitian Survai. Jakarta: LP3ES.

Gerungan, W.A. Psychologi Sosial. 1967. Badung: Eresco.

Gibson, James L., John M. Ivancevich \& James H. Donnelly, Jr. Organization, $10^{\text {th }}$ ed. McGrawHill Higher Edu, 2000.

Handoko, T. Hani. 1992. Manajemen Edisi 2. Yogyakarta; BPFE UGM.

Horton, Paul B. dan Chester L. Hunt. Sosiologi Jilid I. Jakarta: Erlangga, 1996. Erlangga, 1992

Sosiologi Jilid 2. Jakarta:

Krech, David. Sikap Sosial: Social Attitudes. Jakarta: Depdiknas, 1996

Kreitner, Robert dan Angelo Kinicki. Perilaku Organisasi. Jakarta: Salemba Empat, 2003.

Lawang, Robert M.Z. Teori Sosiologi I. Jakarta, Gramedia, 1988.

Lubis, Nilzamni. 2001. Sistem Pembinaan Perpustakaan Perguruan Tinggi dan Permasalahannya, Maktabah, Vol. 3, No. 1, April. Jakarta: UIN Syarif Hidayatullah.

Maslow, Abraham H. 1954. Motivation and Personality. New York: Harper \& Row.

Maslow, Abraham H. 1994. Motivasi dan Kepribadian 1 \& 2: Teori Motivasi dengan Pendekatan Hierarki Kebutuhan Manusia. Jakarta: Grafindo

Marksheffel, Ned D. 1996. Better Reading in the Secondary School [Principles and Procedures for Teachers]. New York: The Ronald Press Company.

McClelland, David C. 1961. The Achieving Society. New York: Van Nostrand.

Meichati, Siti. 1972. Motivasi Pembaca. Yogyakarta: Fak. Psikologi UGM.

Natadjumena, Rachmat. 2005. Masyarakat dan Minat Baca dalam Media Pustakawan Perpusnas RI Vol. 12 [2] Juni 2005. Jakarta: Perpusnas RI.

Poloma, Margaret M. Sosiologi Kontemporer. Jakarta: Rajawali, 1987. 
Priyanto, Ida Fajar. 2005. Buku, Pendidikan, dan Masyarakat, Sangkakala Vol. I [1] 2005. Yogyakarta: Bapusda DIY.

Salusu, J. 1996. Pengambilan Keputusan Stratejik untuk Organisasi Publik dan Organisasi Nonprofit. Jakarta: Grasindo.

Sears, David O., Jonathan L. Freedman, L. Anne Peplau. Psikologi Sosial Jilid I. Jakarta: Erlangga, 1999.

Siagian, Sondang P. 1990. Teori dan Praktek Pengambilan Keputusan. Jakarta: Haji Masagung.

Simamora, Bilson. 2001. ReMarketing for Business Recovery. Jakarta: Gramedia.

Sulistyo-Basuki. 1998. "Total Quality Management untuk Perpustakaan dalam Kepustakawanan Indonesia. Semarang: Unika Soegijapranata

Sutarno NS. 2003. Perpustakaan dan Masyarakat. Jakarta: Yayasan Obor Indonesia.

Walgito, Bimo. Psikologi Sosial: Suatu Pengantar. Yogyakarta, Andi, 2003. 